\section{C-reaktives Protein, ultrasensitiv}

\author{
A. M. Gressner ${ }^{1}$ und O. A. Gressner ${ }^{2}$ \\ ${ }^{1}$ Labor Dr. Wisplinghoff Berlin, Berlin, Deutschland \\ ${ }^{2}$ Labor Dr. Wisplinghoff Köln, Köln, Deutschland
}

Synonym(e) CRP, hochsensitiv

Englischer Begriff C-reactive protein, ultrasensitive, high sensitive

Definition Additiver und unabhängiger Risikoindikator der (entzündlichen) Atherogenese (Koronarsklerose), der auf der Konzentrationsmessung des C-reaktiven Proteins ( $\triangleright \mathrm{C}$ reaktives Protein) innerhalb des Referenzbereichs mittels einer hoch (ultra-)sensitiven Methode beruht.

Beschreibung Unter einem ultrasensitiven CRP wird ein Test verstanden, der in der Lage ist, sehr niedrige CRPKonzentrationen (innerhalb des Referenzbereiches) zuverlässig zu messen. Die Empfehlung besteht, dass der hochsensitive CRP-Test bei einer Konzentration von $0,2 \mathrm{mg} / \mathrm{L}$ eine Unpräzision $<10 \%$ aufweisen darf. Messverfahren sind latexverstärkte $\triangleright$ Immunturbidimetrie, $\triangleright$ Immunnephelomet- rie und $>$ Chemolumineszenz. Die klinische Bedeutung des ultrasensitiven CRP besteht in der prognostischen Beurteilung von Patienten mit instabiler Angina pectoris als additiver Risikofaktor zu den Hauptrisikoindikatoren > Cholesterin, LDL-Cholesterin ( $\triangleright$ Low density lipoprotein), Hypertonie und Nikotinabusus. Patienten mit CRP-Konzentrationen im obersten Quintil ( $>3,6 \mathrm{mg} / \mathrm{L}$ ) haben im Vergleich zu solchen im untersten Quintil $(<0,71 \mathrm{mg} / \mathrm{L})$ ein doppelt so hohes Risiko für ein koronares Ereignis, jedoch ist der prädiktive Wert bei Angina pectoris in neueren Untersuchungen wieder relativiert worden. Pathophysiologisch ist die moderate Konzentrationserhöhung als systemischer Ausdruck der inflammatorischen Komponente der Atherogenese (Koronarsklerose) zu interpretieren, wo CRP möglicherweise direkt am atherothrombotischen Prozess beteiligt ist und in atherosklerotischen Gefäßwänden und an Plasmamembranen geschädigter Zellen lokalisiert ist. Es trägt zur Komplementaktivierung über den klassischen Weg bei.

\section{Literatur}

Danseh J et al (2004) C-reactive protein and other circulation markers of inflammation in the prediction of coronary heart disease. N Engl J Med 350:1387-1397 